\title{
HISPANISMO Y NEUTRALISMO: ARTICULACIONES TRANSNACIONALES EN ESPAÑA Y ARGENTINA DURANTE LA GRAN GUERRA
}

\author{
HISPANISM AND NEUTRALISM: TRANSNATIONAL LINKS BETWEEN \\ SPAIN AND ARGENTINA DURING THE GREAT WAR \\ Maximiliano Fuentes Codera* \\ Universitat de Girona. España
}

\begin{abstract}
RESUMEN: En el marco de la renovación historiográfica de los estudios sobre la Gran Guerra vinculados a la Historia Transnacional, este artículo realiza un estudio centrado en dos países, España y Argentina, que se mantuvieron neutrales durante todo el conflicto. A partir del análisis de documentación de ambos países, pone de relieve que las disputas locales sobre la neutralidad estuvieron relacionadas con dos elementos de carácter transnacional: el combate simbólico por la paz y por el futuro de ambas naciones. En este desarrollo, la proyección del hispanismo contribuyó decisivamente en la configuración de un espacio neutralista y germanófilo compartido entre ambas geografías. Los elementos que lo conformaron, como se muestra al final del artículo, fueron centrales en la conformación del renovado hispanismo que formularían las derechas reaccionarias en los años veinte y treinta, tanto en Argentina como en España.
\end{abstract}

PALABRAS CLAVE: Primera Guerra Mundial; Neutralismo; España; Argentina; Hispanismo; Historia Transnacional

ABSTRACT: Within the framework of the historiographic renewal of the studies on the Great War linked to Transnational History, this article carries out a study centered on two countries, Spain and Argentina, which remained neutral throughout the conflict. Based on the analysis of documentation from both countries, it highlights that the local disputes over neutrality were related to two transnational elements: the symbolic struggle for peace and for the future of both nations. In this development, the projection of Hispanism contributed decisively to the configuration of a neutralist and pro-Germany space shared by both countries. The elements that made it up, as shown at the end of the article, were central to the formation of the renewed Hispanism that the reactionary right-wing groups formulated in the 1920s and 1930s, also in both countries.

KEYWORDS: World War I; Neutralism; Spain; Argentina; Hispanism; Transnational History.

* Correspondencia a: Maximiliano Fuentes Codera. Universitat de Girona, Facultat de Lletres, Departament d'Història i Història de I'Art, Plaça Ferrater Mora, 1, 17004-Girona (Spain). - maximiliano.fuentes@udg.edu - https://orcid. org/0000-0001-9793-2100.

Cómo citar: Fuentes Codera, Maximiliano (2020). «Hispanismo y neutralismo: articulaciones transnacionales en España y Argentina durante la Gran Guerra»; Historia Contemporánea, 63, 419-452. (https://doi.org/10.1387/hc. 21163).

Recibido: 18 octubre, 2019; aceptado: 20 enero, 2020.

ISSN 1130-2402 - eISSN 2340-0277 / (C) 2020 UPV/EHU

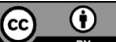

Esta obra está bajo una licencia

Creative Commons Atribución 4.0 Internacional 


\section{Introducción}

El hecho de que en noviembre de 1918 solamente unos pocos estados se mantuvieran neutrales en el mundo sugiere que la capacidad de hacerlo durante la Primera Guerra Mundial fue más la excepción que la regla. En este marco, parece fácil entender por qué el estudio del impacto de la guerra en los países neutrales ha sido significativamente menos relevante que el de aquellos que intervinieron en el conflicto. Sin embargo, en los últimos años, la historia de las neutralidades ha comenzado a insertarse en una visión del conflicto cada vez más concebida desde el punto de vista de la historia transnacional y la historia global.

Desde hace casi dos décadas, y al compás del giro transnacional y glo$\mathrm{bal}^{1}$, las visiones generales de la guerra comenzaron a ensanchar sus horizontes de análisis. Las razones las planteaba John Horne en 2011: «The paradox is that the nation-state and national efforts were central to the First World War but in order to understand how and why was so, national frameworks are insufficient». Por muchos motivos, desde las formas imperiales y «prenacionales» que dominaban una parte significativa del mundo hasta la «totalización» del conflicto, afirmaba que comprender el conflicto exigía «a sense of different national trajectories that only a comparative sensibility can measure just as it calls for a willingness to look in transnational terms at the processes at work ${ }^{2}$. En los años posteriores, se multiplicaron las obras que asumieron el propósito de deseuropeizar la guerra, al punto que algunos autores llegaron a hablar de una «guerra-mundo ${ }^{3}$. En este contexto, la publicación de The Cambridge History of the First World War demostró que esta interpretación transnacional de la guerra se ha convertido en dominante. En la introducción a dicha obra, Jay Winter, su editor, afirmaba que se había llegado a la «transnational generation» de historiadores, que tenía como característica «to see the conflict as trans-European, transatlantic and beyond $»^{4}$.

La experiencia de los países neutrales, como decíamos, fue durante mucho tiempo desatendida. La narrativa de los beligerantes ocupó el centro de las preocupaciones. Esto se conjugó con unas miradas estrechas, nacionales, de las historiografías producidas en los países neu-

1 Olstein, 2014.

2 Horne, 2011, p. xv.

3 Neiberg, 2005; Gerwarth y Manela, 2014; Frank, 2016.

4 Winter, 2014, p. 6. 
trales. Sin embargo, como recordaba Carolina García Sanz, el lugar secundario otorgado a los neutrales contrastaba con su centralidad en el desencadenamiento de las hostilidades. En este sentido, aunque esté lejos de ser excepcional, el caso de Bélgica resulta emblemático ${ }^{5}$. Como afirmaron Pierre Purseigle y Olivier Compagnon, los países neutrales no solamente resultaron afectados por la guerra, fueron también actores de ella. Por ello, escribir una historia global de la conflagración supone establecer una distinción crítica entre lo que los anglófonos denominan belligerency y belligerence: mientras que el primer concepto refiere a un estatus definido por el derecho internacional - el estado de guerra-, el segundo lo hace a un proceso de adaptación u organización en el contexto bélico. Así, a pesar de que sus Estados fueran neutrales, las sociedades escandinavas, latinoamericanas o española fueron beligerantes - en el sentido del concepto belligerence - , ya que expresaron variados procesos de movilización y múltiples tensiones internas y externas derivadas del conflicto $^{6}$. Estos países neutrales estuvieron sometidos a procesos de negociación en relación con la presión militar y comercial e intentaron maximizar los beneficios de su situación en el escenario internacional ${ }^{7}$. Como planteó Maartje Abbenhuis, «Neutrality is never about the experience of one state and its people. Instead it is the international environment and the relationship between states that determine the circumstances and legitimacy of neutrality» ${ }^{8}$. En este marco, como han mostrado diversos trabajos, el debate sobre las naciones tuvo una importancia fundamental para articular los discursos sobre el devenir político de los países neutrales, incluso durante las décadas posteriores a la guerra ${ }^{9}$.

Teniendo en cuenta todos estos elementos, resulta pertinente poner en relación algunos aspectos - entre los diversos que podrían tratarse - que vinculan dos países neutrales, España y Argentina, con lo acontecido en los países beligerantes ${ }^{10}$. La condición de neutrales de ambos países durante todo el conflicto, la composición social e identitaria de Argentina - una sociedad cuya población contaba con cerca del 30\% de inmigran-

5 García Sanz, 2016.

${ }^{6}$ Compagnon y Purseigle, 2016.

7 Kruizinga, 2014.

8 Abbenhuis, 2016, p. 20.

9 Algunos ejemplos: Sturfelt, 2012; Tames, 2012; Fuentes Codera, 2014.

10 Una primera aproximación al estudio de ambos países, en García Sanz y Tato, 2017. 
tes en 1914, y que en Buenos Aires llegaba a un $49 \%^{11}-\mathrm{y}$ las estrechas relaciones culturales durante las primeras décadas del siglo pasado justifican esta propuesta ${ }^{12}$. En este marco general, la proyección y la utilización del concepto de hispanismo permitió la estructuración de un espacio transnacional que se plasmó localmente en ambas geografías ${ }^{13}$. Dicho espacio transnacional se articuló a través de personas, proyectos políticos y discursos sobre la neutralidad, la paz, Francia, Inglaterra, Alemania y también España, Argentina y los países neutrales. En él, los neutralismos, diversas germanofilias y unas constantes y cambiantes apelaciones al hispanismo dotaron a los sectores que simpatizaban con las Potencias Centrales en cada país de una coherencia que fue central para fundamentar sus planteamientos. Teniendo en cuenta estos elementos, este artículo tiene como objetivo analizar la neutralidad desde la perspectiva de la historia transnacional, sin dejar de lado los desarrollos locales-nacionales e intentando comprenderlos en su relación con las circulaciones internacionales que se produjeron ${ }^{14}$. Como escribió William Mulligan, «Ideas were reworked in national and local contexts, but their legitimacy rested on transnational contexts» ${ }^{15}$.

\section{La disputa por la neutralidad}

Tanto España como Argentina se declararon oficialmente neutrales al estallar el conflicto. Sin embargo, el impacto de la guerra se sintió con intensidad desde los primeros días de agosto de 1914. En las principales ciudades de ambos países multitudes se agolparon frente a las redacciones de los principales periódicos para conocer de primera mano las noticias que llegaban desde el frente. También se observaron grandes colas en los bancos franceses e ingleses, tanto en España como en Argentina, ante el caos financiero desatado ${ }^{16}$.

${ }^{11}$ Tercer Censo levantado el 1..$^{\circ}$ de junio de 1914, Buenos Aires, Talleres Gráficos L. J. Rosso \& Cía., 1916, Volumen II, p. 396.

12 Figallo, 2014.

13 Utilizo aquí la idea de espacio transnacional en el sentido planteado en Alcalde, 2018.

14 Gupta, 1992.

15 Mulligan, 2016, p. 323.

16 Martorell, 2011; Sánchez, 2018. 
En España, frente al inicio de las hostilidades en Europa, el gabinete de Eduardo Dato, con el acuerdo de Alfonso XIII, se apresuró a declarar la neutralidad. Durante los primeros meses, a pesar de algunas declaraciones ciertamente disonantes de Alejandro Lerroux, Melquíades Álvarez y el conde de Romanones, la neutralidad estuvo lejos de estar cuestionada. No solamente los partidos dinásticos sostuvieron la posición oficial, sino que incluso sectores republicanos y el Partido Socialista plantearon que no debía cuestionarse la neutralidad. No obstante, pronto esta situación dio paso otra muchísimo más compleja.

Durante las semanas posteriores, una incipiente división de la sociedad española en dos campos - que en su interior albergaban grupos, individuos e intereses políticos y culturales no siempre convergentes - se fue definiendo con mayor claridad. Los sectores favorables a los Aliados y los simpatizantes de la causa alemana mostraron que los posicionamientos sobre la guerra estaban directamente relacionados con unos proyectos políticos y nacionales concretos. Esquemáticamente, entre los simpatizantes de las Potencias Centrales destacaron la Corte - con la notable excepción de Alfonso XIII - y el conjunto de la aristocracia, liderados por María Cristina, las altas jerarquías del Ejército, la mayoría de la Iglesia católica y los partidos carlista y maurista. Entre los partidarios de los aliados resaltaron los diversos agrupamientos republicanos, los partidos socialista y reformista, y la mayoría de los intelectuales. En este marco, los aliadófilos se apresuraron por vincular la guerra a la política española. También lo hicieron los germanófilos, como demostró Vázquez de Mella, uno de sus más destacados líderes. Sin embargo, los más interesados en que los debates sobre la guerra se extendieran al conjunto del país fueron los partidarios de los Aliados y especialmente los francófilos. En sintonía con los planteamientos de la propaganda aliada, interpretaron el conflicto como una disputa entre la autocracia germana y las democracias francesa e inglesa, como una lucha entre naciones e imperios que debía marcar el futuro del país ${ }^{17}$.

En Argentina, la neutralidad asumida por el conservador Victorino de la Plaza, quien gobernaría hasta octubre de 1916, tampoco fue excesivamente discutida. A pesar de que existió un consenso acerca de que esta posición era la más adecuada para preservar los intereses económicos argentinos y evitar tensiones culturales y políticas derivadas del ca-

${ }^{17}$ Fuentes Codera, 2014, pp. 61-111. 
rácter cosmopolita de la sociedad, esto no fue óbice para que, como en España, los posicionamientos se establecieran con cierta claridad. En líneas generales, la sociedad simpatizó mayoritariamente con los Aliados, especialmente con Francia, que desde el siglo anterior representaba un modelo para las elites culturales y políticas ${ }^{18}$. La presencia de importantes comunidades italiana, francesa, británica, rusa y sirio-libanesa, entre otras, contribuyó a reforzar esta simpatía. En medio de estas comunidades - que llevaron a que en Argentina la movilización fuese notablemente mayor a la que se experimentaba en España-, los españoles reproducían la división que se observaba en la península, expresando opciones aliadófilas (mayoritaria) y germanófilas ${ }^{19}$. La mayoría de los periódicos y los intelectuales también simpatizaron con los Aliados. Entre los partidarios de Alemania destacaban algunos intelectuales, la comunidad alemana y su embajada y el periódico La Unión. Socialmente, la influencia alemana se limitó a ciertos sectores como el militar y el católico, y también se observó en ciertas profesiones liberales, como los estudiantes, abogados, profesores y médicos. En este marco, como en España, los sectores que se mantuvieron al margen de las polarizaciones fueron minoritarios.

En esta primera parte del conflicto, la incipiente movilización se expresó a través de asociaciones y comités patrióticos - como el Comité Argentino Pro Huérfanos Belgas y el Comité Franco-Argentino- que sirvieron, entre otras cosas, para canalizar envíos de dinero y otros recursos a sus respectivas patrias. En este desarrollo, tuvo lugar un proceso que se expresó a través de unos parámetros similares a los españoles. Aliadófilos y germanófilos debatieron con intensidad en los periódicos acerca de los orígenes de la guerra y la caracterización de las potencias enfrentadas en los campos de batalla. Estos debates se expresaron de forma binaria: el contraste entre la violencia germana se enfrentaba como un todo a una supuesta unánime coalición aliada representante del derecho y la democracia. En este esquema construido por los simpatizantes de Francia e Inglaterra, por supuesto, Rusia era convenientemente olvidada. Del otro lado, los partidarios de las Potencias Centrales impugnaban dichos planteamientos y afirmaban que Alemania representaba unos valores - jerarquía, orden, socialismo de Estado, ciencia, cultura - que podían y debían

\footnotetext{
18 Rolland, 2000.

19 Tato, 2014.
} 
ayudar a cambiar las sociedades argentina y española. En este contexto, la propaganda beligerante y los debates que se desarrollaban en Europa configuraban el marco interpretativo ${ }^{20}$.

Como en Argentina, en España la tensión entre aliadófilos y germanófilos no fue solamente una polémica sobre los valores culturales, científicos o filosóficos de Alemania, Francia o Inglaterra. Se trató, en realidad, de una polémica que, percibida tanto en clave interna como internacional, acabó por impregnar al conjunto de las sociedades. La guerra no solamente se había convertido en unos de los ejes centrales del debate intelectual, también había devenido una fuente de enfrentamientos sociales, al punto de que en 1915 el ministro de la Gobernación español, José Sánchez Guerra, decidió retirar de la Puerta del Sol los transparentes que exhibían las primeras planas de los periódicos ya que las discusiones en torno a lo que allí aparecía solían acabar con «manifestaciones contrapuestas» ${ }^{21}$. La misma tensión se observó en Zaragoza, donde llegó a prohibirse la proyección de películas alemanas en noviembre de 1916 por las mismas razones $^{22}$. La guerra era reinterpretada de acuerdo con los condicionantes locales a través de diversas intermediaciones, que iban desde las publicaciones locales hasta el cine, pasando por espacios de sociabilidad diversos, mítines incluidos. Esta mediación se encontraba atravesada por la situación económica y social. Además de los fenómenos migratorios - los miles de trabajadores repatriados a los países beligerantes, los españoles que regresaron de los países en guerra - que habían sacudido algunas zonas del país, el comercio internacional se había visto profundamente afectado por la guerra ${ }^{23}$.

Durante la primera mitad de la guerra, la neutralidad oficial impuso los marcos de los debates y, en cierto modo, se convirtió en un espacio de disputa. Este espacio, además de las características «nacionales», tuvo como elementos centrales las imágenes del «otro» generadas por los diferentes países beligerantes tanto de la propia metrópoli como de las embajadas y consulados ${ }^{24}$. Numerosos ejemplos demuestran estos procesos: desde traducciones al inglés o francés de obras escritas por autores espa-

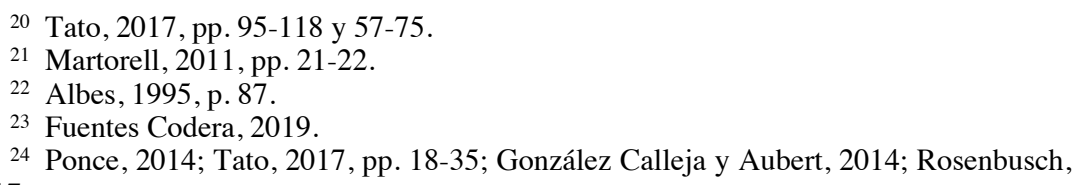
2017. 
ñoles y argentinos hasta libros producidos en países beligerantes traducidos al español con el objetivo de influir en la opinión pública ${ }^{25}$. Estas imágenes del «otro» fueron articuladas en términos transnacionales: no solo fueron «importadas» en Argentina y España sino que fueron reinterpretadas en estos países. En este sentido, para mostrar un ejemplo, la idea de Alemania y sus científicos como referentes de la modernidad apareció con gran fuerza entre los intelectuales germanófilos españoles y argentinos ${ }^{26}$. En este marco, los debates sobre la responsabilidad del inicio de la guerra y la invasión alemana de Bélgica, que estuvieron marcados por la lucha por la apropiación de los conceptos de paz y neutralidad, fueron centrales. Para los aliadófilos argentinos, el ejemplo de Bélgica mostraba que era fundamental apoyar a Francia e Inglaterra, ya que representaban un «consolador testimonio de la civilización que no sucumbe» y testimoniaban que los representantes de la «raza latina», marchaban «a la vanguardia en la batalla gigantesca contra el neosalvajismo» ${ }^{27}$. Bélgica había sido, afirmaba el argentino Francisco Barroetaveña, «la violación mas flagrante» llevada a cabo por Alemania frente a Francia, «un foco de civilización expansiva y humanitaria como ninguna ${ }^{28}$. La idea de Bélgica como símbolo de heroísmo y martirio era compartida por el amplio arco aliadófilo español $^{29}$. Desde el otro lado, el principal periódico germanófilo argentino, La Unión, afirmó que, a la luz de los documentos hallados por los alemanes en los archivos de Bruselas, resultaba evidente «antes de estallar la guerra Bélgica había dejado ya de ser un Estado neutral, sino un vasallo de la Triple Entente, enemiga de Alemania». Alemania simplemente se había limitado a defender la «conservación de la propia existencia» ${ }^{30}$. Las llamadas «atrocidades alemanas» se articularon, pues, de manera transna-

25 Algunos ejemplos: Alemania por encima de todo: la mentalidad alemana y la guerra, París, Armand Colin, 1915; La verdad de la guerra, Barcelona, Germania, 1916; ¿Cómo puede ser justa la guerra alguna vez?, Londres, Thomas \& Lilly, 1915; Inglaterra ante el espejo de la verdad: juicios de intelectuales de diversas naciones, incluso la británica, sobre el verdadero carácter inglés, Buenos Aires, 1918; Melgar, 1916.

26 André, 1915; Quesada, 1914.

27 Ernesto de la Guardia, «El ideal de la redención a través de los tiempos. La Alemania romántica y la Prusia militarista», Nosotros, octubre de 1915, pp. 53-75.

${ }_{28}$ Barroetaveña, 1916, pp. 96, 100 y 101.

29 «Por la paz. La acción de los neutrales» y Rafael Sánchez Ocaña, «Desde París. La unidad moral de Francia», El País, 11 de agosto de 1914; Joan Roig, «Espanya i Bélgica», Empordà Federal, 10 de abril de 1915

30 «La neutralidad belga», La Unión, 14 de noviembre de 1914. 
cional, ya que los testimonios de diversos países neutrales - Dinamarca, Holanda, entre otros - eran utilizados para fundamentar los planteamientos locales sobre las naciones ${ }^{31}$.

\section{Neutralidad y patriotismo}

Dentro de los amplios campos germanófilos y neutralistas argentino y español, dos revistas homónimas, ambas subvencionadas por la propaganda alemana, mostraron los múltiples vínculos transnacionales entre ambos países ${ }^{32}$. La revista Germania se publicó en Buenos Aires entre el 1 de junio de 1915 y el 16 de mayo de 1916. Propiedad del industrial argentino Eduardo Retienne y dirigida por Pablo Fabats, contaba con el «protectorado honorario» del conde Luxburg - embajador alemán en Buenos Aires - y sus beneficios estaban destinados a la Cruz Roja alemana. Ambas características ilustran con claridad el vínculo que pretendía proyectar dicha publicación entre Alemania y la defensa de la paz. Se trata de un elemento común presente en toda la propaganda alemana difundida en los países neutrales, que tenía como objetivo contrarrestar la visión aliada y aliadófila de Alemania como potencia militarista e imperialista ${ }^{33}$.

$\mathrm{Su}$ alineamiento con la causa alemana era total y tenía como objetivo hacer frente a la influencia de los Aliados en la sociedad argentina $^{34}$. Por ello, era habitual encontrar en sus números fotografías de militares y altos funcionarios del Estado y largos artículos sobre aspectos de la vida militar alemana. La defensa de la causa alemana se fundamentaba, como era habitual, en la idea de que estaba llevando a cabo una guerra defensiva, según la cual Alemania simplemente había entrado en el conflicto para responder a una Inglaterra avasallante ${ }^{35}$. Vale la pena recordarlo, este era un elemento fundamental que se observaba

31 «La voz de los neutrales», La Unión, 30 de diciembre de 1914. La explicación más completa sobre las «atrocidades alemanas» en Horne y Kramer, 2001; para el impacto en Argentina: Sánchez, 2014,pp. 134-148.

32 Sobre los campos germanófilos de ambos países, véanse Fuentes Codera, 2014; Alonso, 2017; Tato, 2017.

33 Welch, 2014.

34 «La prensa alemana y “Germania”», Germania, 1 de enero de 1916.

35 Johannes Reinke, «Pueblo y Estado», Germania, 1 de enero de 1916. 
en las potencias en guerra, en las cuales el mismo argumento se empleaba para movilizar las retaguardias ${ }^{36}$.

Sin embargo, no todo lo que allí se publicaba hacía referencia a aspectos de la vida alemana. También aparecieron largos textos escritos por algunos de los principales intelectuales germanófilos argentinos. Uno de ellos fue una larga transcripción de la interpelación al Poder Ejecutivo argentino pronunciada el 5 de diciembre de 1915 en el Congreso por el diputado conservador y ex ministro de Relaciones Exteriores Estanislao Zeballos en relación con el apresamiento del barco «Presidente Mitre». Se trataba de un vapor de bandera argentina destinado a la navegación costera que había sido interceptado el 28 de noviembre por el crucero británico «Orama» a doce millas de Punta Médanos. Frente a este incidente, el gobierno argentino no había reclamado compensación alguna a pesar de la evidente violación de la neutralidad ${ }^{37} \mathrm{y}$, por ello, la intervención de Zeballos condenaba la ofensa infringida por Inglaterra y afirmaba la «justicia» de la causa alemana y su cercanía con la defensa de Argentina ${ }^{38}$.

Germania combinaba una clara defensa de los Imperios Centrales con una perspectiva nacionalista argentina muy evidente ${ }^{39}$. Así lo demostraba su insistencia en la necesidad de contrarrestar las influencias de los «mal llamados pueblos latinos», que eran «ajenas a nuestra condición y raza». La guerra era una excelente oportunidad para «liquidar» los valores morales latinos y británicos y abrir Argentina hacia el influjo de Alemania. «¿Cómo comprender que una nación que entró en guerra en nombre de la justicia y del derecho, por la violación, según dijo, de la neutralidad de Bélgica, no tenga el menor escrúpulo en atropellar en toda forma la de Grecia?», preguntaba el escritor y ensayista Calixto Oyuela. Por ello, pensaba que lo que necesitaba la nación argentina era «penetrar, conocer a fondo el verdadero y gran espíritu germánico, intimando con él y recibiendo directamente su influencia» para «enriquecer» las cualidades nacionales $^{40}$. Alemania era un pueblo de «pacífico desarrollo» que antes de la guerra «aumentaba sus votos democráticos por millones en cada nueva

36 Neiberg, 2011.

37 Lanús, 2001, pp. 65-72.

38 «Interpelación al Poder Ejecutivo de la Nación sobre el apresamiento del "Presidente Mitre"», Germania, 1 de enero de 1916.

39 «25 de mayo (1810-1916)», Germania, 16 de mayo de 1916.

40 Calixto Oyuela, «Alemania en Argentina. I», Germania, 15 de enero de 1916. 
elección». Tanto las ideas alemanas de «la libertad y de la vida» como su «noble espíritu de disciplina, de dependencia necesaria» era «la mayor lección y la influencia más saludable que los argentinos podemos recibir de Alemania» ${ }^{41}$. Esta era la conclusión de este largo y programático artículo dividido en dos entregas. En medio de ellas apareció un número de la revista dedicado al Káiser Guillermo II en su cumpleaños. Calixto Oyuela le dedicaba un efusivo saludo en el que se mezclaban «la gracia de Dios y el corazón de la patria» ${ }^{42}$.

Los vínculos con España pronto se hicieron evidentes a través de diversos artículos en los que se hablaba sobre sus ciudades y pueblos $^{43}$. Sin embargo, la relevancia de España iba mucho más allá de una cuestión pintoresca. Los vínculos históricos, una proyección hispanista que pusiera en cuestión la influencia latina y el creciente prestigio del rey Alfonso XIII eran elementos fundamentales. Por ello, Germania dedicó un número especial a España el 2 de mayo de 1916. La efeméride no era casual y respondía a una lectura histórica que pretendía poner en cuestión los lazos entre Francia y España y, en consecuencia, entre Francia y Argentina. El número se abría con una ilustración del Quijote y un artículo dedicado a Cervantes en los trescientos años de su muerte. Esta referencia al Quijote no era aleatoria: la identificación de la neutralidad con el carácter caballeresco de la España neutral también aparecía en otras publicaciones de la comunidad española argentina ${ }^{44}$. El número de Germania estaba lleno de reminiscencias y proyecciones hispanistas que rechazaban la influencia francesa y tenían como objetivo central afirmar que España estaba salvando con su neutralidad «las últimas nociones de lo honrado, de lo digno, de lo justo» ${ }^{45}$. Enormes fotos del rey Alfonso XIII y la reina Victoria ilustraban este número, que presentaba también dos artículos dedicados a atacar directamente a Inglaterra, uno centrado en el «abuso» británico en los mares, que había sido experimentado por Argentina con el «Presidente Mitre», y otro que pretendía demostrar la «presión brutal» in-

41 Calixto Oyuela, «Alemania en Argentina. II», Germania, 16 de abril de 1916.

42 «Homenaje de Germania a S. M. Guillermo II», Germania, 27 de enero de 1916.

43 «Castillo y Monasterio de Perelada (España)», 27 de enero de 1916.

44 «Pleitesía», La Gaceta de España. Periódico español de la tarde, 22 de abril de 1916. Todo este número estaba dedicado a Cervantes. Agradezco al profesor Javier Moreno Luzón la referencia a esta fuente.

45 Julio del Romero Leyva, «Homenaje a España», Germania, 2 de mayo de 1916. 
glesa sobre Gibraltar, donde con el fin de la guerra volvería a «flamear la gloriosa bandera española» ${ }^{46}$. El número especial incluía también una nota necrológica dedicada a Germán Tarjks, director de los periódicos germanófilos La Unión y Deutsche La Plata Zeitung, que había fallecido el 24 de abril.

Se articulaba así una idea de España que no se encontraba nada lejos de la que propugnaba la homónima Germania, que se publicó quincenalmente en Barcelona entre el 1 de marzo de 1915 y el 15 de noviembre de 1918 con patrocinio económico alemán y la dirección de Luis Almerich. Su tirada aproximada fue de 3.000 ejemplares ${ }^{47}$. Como en la revista argentina, las ideas de su primer editorial relacionaban estrechamente democracia y decadencia del latinismo - «seguir la corriente de las tradiciones latinas es caminar hacia la muerte» - representado por Francia y secundado por Gran Bretaña. Frente a ellos, afirmaba la proyección de una Alemania «joven y animosa, rebosante de fe» que, por su pujanza científica, había sabido atraer una parte significativa de lo mejor de la juventud española que había acudido a sus universidades en busca de una formación que la cultura francesa había dejado de ofrecerle.

Frente a una España que decaía por la influencia latina, Germania, como su homónima argentina, sostenía que la neutralidad era «hispanófila» ${ }^{48}$ y buscaba potenciar la «esperanza de resurgimiento» y demostrar que «el espíritu nacional no ha muerto» ${ }^{49}$. Así, neutralismo y patriotismo español se fueron convirtiendo en sinónimos y la supuesta «incapacidad» representada por la posición oficial fue deviniendo sinónimo de vitalidad, optimismo y acercamiento a una Alemania que, vencedora, devolvería la gloria a la nación ${ }^{50}$. Por ello, no era casual que uno de los colaboradores de la revista, Faustino Ballvé, encabezara la Federación Neutralista Catalana, que continuaba la labor neutralista del marqués de Polavieja (hijo) ${ }^{51}$. Tampoco lo era que la revista, junto a otras publica-

46 A. Jason, «El terrorismo británico», Germania, 2 de mayo de 1916; P. Jason, «Gibraltar», Germania, 2 de mayo de 1916.

47 Aubert, 1995, p. 116

48 Delfín Álvarez y González, «Maura, hispanófilo», Germania, 1 de mayo de 1915, pp. 6-8.

49 Ángel Ruiz y Pablo, «La actitud de España ante la guerra», Germania, 15 de abril de 1916,pp. 77-81.

${ }^{50}$ M. García y Panadés, «Patriotismo sin convicción», Germania, 15 de febrero de 1916, pp. 3-4.

51 «Campaña neutralista», Germania, 1 de marzo de 1917, p. 14. 
ciones germanófilas, apoyara la extensión de unas juntas neutralistas en el conjunto del territorio español ${ }^{52}$.

La mayoría de los elementos que aparecían en esta revista - la proyección de España y Alfonso XIII como modelos de humanitarismo, pacifismo y neutralismo, la defensa de los valores científicos y políticos de Alemania, y la vinculación de las ideas de neutralismo y patriotismofueron fundamentales para mostrar cómo se articuló un espacio transnacional que vinculó ambos países con las potencias beligerantes. En este sentido, resulta especialmente interesante observar cómo la política de neutralidad de Alfonso XIII fue tanto un modelo de «independencia» nacional para los sectores neutralistas argentinos como una demostración de falta de patriotismo para los sectores aliadófilos españoles. El monarca también fue un ejemplo de humanitarismo, pacifismo y neutralidad para los sectores germanófilos argentinos, que no dudaron en destacar su papel al frente de la Oficina Pro-Cautivos ${ }^{53}$.

Este proceso tuvo un largo desarrollo que se extendió durante toda la guerra y que se observó ya poco tiempo después del inicio del conflicto. En un artículo publicado en La Esfera en marzo de 1915 Eloy Luis André, filósofo formado en Alemania, traductor de Wilhelm Wundt y Rudolf Eucken y catedrático del Instituto de Toledo, planteaba con claridad el rechazo a uno de los argumentos europeizantes de los intelectuales aliadófilos españoles: «¿Cómo es posible conciliar la verdadera neutralidad de España con el más genuino españolismo?». La neutralidad debía ser una oportunidad para «formar una conciencia nacional y nacionalizar la tierra y el espíritu español», pero el camino no era el de la «europeización» sino el de la unión entre el españolismo y el neutralismo. Se trataba de enfrentarse a «esos cuervos de la europeización que graznan aquí el himno de la guerra» ${ }^{54}$. A diferencia de lo que planteaban Ortega y Araquistáin, la regeneración española pasaba por una neutralidad interpretada como política activa y expresión de independencia y autonomía. Se trataba de un argumento similar al que sostendría meses más tarde Juan Pujol, corresponsal de $A B C$ en Londres $-\mathrm{y}$ en los años treinta, colaborador de publicaciones centrales de la derecha reaccionaria, como Acción Española e Informaciones, de la

\footnotetext{
52 «Por la neutralidad. Listas de afiliados a los Comités de provincias», La Nación, 20 de febrero de 1917, p. 5.

53 Barral Martínez, 2019.

54 Eloy Luis André, «Neutralidad y españolismo», La Esfera, 13 de marzo de 1915.
} 
cual fue director-, al denunciar la «provocación contra la mayoría de la nación» que estaban protagonizando los sectores aliadófilos. La vinculación entre la paz, la neutralidad y la independencia nacional aparecía con total claridad en su crítica a los intelectuales institucionistas que pretendían acabar «con la paz de un pueblo»: «iCelosos del honor nacional los que se han mofado del patriotismo, y han procurado por todos los medios a su alcance fomentar el internacionalismo disolvente, y colaborar con los publicistas extranjeros en la tarea de manchar la historia de España! ${ }^{55}$. No casualmente, en la misma página de $\mathrm{La} \mathrm{Na}$ ción en la que aparecía este artículo de Pujol, se publicaba otro texto titulado «Unidad hispanoamericana». Allí se afirmaba que «Ni los Estados Unidos están ligados por vínculos morales a las repúblicas hispanoamericanas ni la hegemonía moral de España sobre ellas se ha de alcanzar formando la vieja metrópoli con sus antiguas colonias una manada contra Alemania». El autor era Vicente Gay, uno de los más destacados germanófilos españoles y entonces catedrático de Valladolid (más tarde sería el contacto de la embajada alemana para el proyecto alemán de creación de un instituto artístico en Madrid en la inmediata posguerra, colaborador de Acción Española y delegado de Prensa y Propaganda del Estado en Burgos). Su conclusión mostraba claramente los vínculos entre los conceptos mencionados. Aparecían allí entrelazadas las ideas sobre la paz, la neutralidad, la nación española y su proyección hispanista, todo ello en abierta oposición a los sectores partidarios de Francia e Inglaterra: «Nuestros intervencionistas no van por el camino de la paz y de la cultura para conseguir la unidad espiritual con América; nos preconizan el camino de la fuerza». En el marco de la guerra, argumentaba, se trataba de impulsar una «reconquista» intelectual a través de las embajadas intelectuales. El trasfondo era la defensa de una cierta idea de paz que unía hispanismo y neutralismo. No era extraño. Desde la invasión alemana de Bélgica hasta el final de la guerra, la defensa de la paz y la neutralidad fueron elementos centrales en la configuración de los argumentos que sustentaron local y transnacionalmente las posiciones de los partidarios de uno y otro bando. Como sostuvo William Mulligan, «Peace was at the centre of the First World War, providing meaning to the conflict» ${ }^{56}$.

\footnotetext{
55 Juan Pujol, «Intervención y patriotismo», La Nación, 28 de abril de 1917.

${ }^{56}$ Mulligan, 2014,p. 4.
} 


\section{Hispanismo y latinismo, neutralidad e intervención}

La neutralidad fue un espacio de disputa que dotó de sentido político los posicionamientos sobre la guerra a nivel local. A pesar de que esto se expresó durante todo el conflicto, como sucedió en la mayor parte del mundo, esta tensión tuvo un punto de inflexión en 1917. Diversos procesos internacionales afectaron la manera en que fue percibida la guerra en los países. En el marco internacional, la declaración del inicio de la guerra submarina indiscriminada por parte de Alemania en enero y, dos meses más tarde, la caída de la monarquía en Rusia dieron un claro impulso a los partidarios del fin de la guerra. A ello se sumó la declaración de guerra de los Estados Unidos el 6 de abril, motivada por su intención de convertir el mundo en un lugar seguro para la democracia, según afirmó Woodrow Wilson. En noviembre, el triunfo bolchevique abrió definitivamente un nuevo período histórico, que acabaría conduciendo a la salida unilateral de la Rusia revolucionaria de la guerra en marzo del año siguiente ${ }^{57}$. Todos estos elementos contribuyeron decisivamente a la radicalización política en España y Argentina.

En España, después de la caída del conservador Eduardo Dato en diciembre de 1915, comenzó un período liderado por el conde de Romanones en el cual se demostró que la cuestión de la neutralidad estaba directamente relacionada con los múltiples conflictos que se estaban desarrollando internamente. En 1917, coincidiendo con lo que sucedía en el conjunto del continente europeo, la situación llegó a la máxima tensión. Diferentes grupos sociales - el movimiento obrero, la burguesía industrial catalana y el ejército - recurrieron a soluciones corporativas mediante las cuales consideraron que podían estar mejor protegidos sus intereses particulares ${ }^{58}$. Cuando abandonó el poder en abril de 1917, Romanones dejó un Partido Liberal resquebrajado y un movimiento obrero, una burguesía y un ejército que esperaban ansiosamente el momento de asestar el golpe definitivo al turno dinástico. Con su autoproclamada simpatía por la Entente, la polarización ideológica del país llegó a su punto más álgido ${ }^{59}$. En este proceso, además de los propios elementos internos, fueron fundamentales la lectura hecha en clave local del proceso revolucionario ruso y de

\footnotetext{
57 Stevenson, 2017.

58 González Calleja, 2017.

59 Romero Salvadó, 2002, pp. 70-99.
} 
la influencia ejercida por la entrada de Estados Unidos en la guerra, y en particular de la figura de Woodrow Wilson ${ }^{60}$.

En Argentina, la llegada al poder del radical Hipólito Irigoyen en octubre de 1916 había abierto una nueva época marcada por la ampliación de la participación política. El cambio en la situación internacional provocó un impacto local que tuvo en cuenta todos los elementos anteriores. El detonante de la movilización fue el hundimiento de tres buques de carga entre abril y junio. Bajo la bandera del panamericanismo, los ataques a estos tres vapores fueron utilizados por el gobierno de los Estados Unidos para incitar a Argentina a abandonar la neutralidad. Con este fin, desde Washington se hicieron públicos los mensajes secretos enviados a su gobierno por el ministro alemán en Argentina, el conde Karl von Luxburg, que había sido descifrado en Londres y comunicado a Washington. En ellos, el diplomático alemán se refería al Ministro de Relaciones Exteriores local, Honorio Pueyrredón, como «un conocido burro y anglófilo», y recomendaba seguir atacando a los buques argentinos «sin dejar rastro» ${ }^{61}$. En Argentina, los opositores al radicalismo, con una fuerte presencia del Comité Nacional de la Juventud, denunciaron que el presidente no atendía a la voluntad popular que se expresaba en las calles y la prensa. En este marco, apoyaron al Congreso Nacional (un reducto controlado entonces por la oposición), que se había manifestado mayormente a favor de la ruptura de relaciones con Alemania en 1917. En España se manifestó un proceso similar: los sectores favorables a los aliados sostuvieron la necesidad de romper con Alemania mientras que los sectores neutralistas advirtieron sobre el peligro de que una ruptura de relaciones acabara conduciendo al $\operatorname{cass}^{62}$.

A partir de entonces, conceptos como germanófilo y aliadófilo comenzaron a usarse en las luchas políticas como sinónimos de antipatriótico y antinacional. Se llevaron a cabo manifestaciones masivas - en algunos casos con la participación de las sesenta mil personas- organizadas por varias asociaciones surgidas en diversas áreas sociales y geográficas $^{63}$. Desde 1917, en los sectores germanófilos y neutralistas la oposición entre los términos «intervención» y «neutralismo» se convirtió en una evidencia tanto en Argentina - también en el conjunto de Amé-

\footnotetext{
${ }^{60}$ Rinke y Widt, 2017; Fuentes Codera, 2020.

61 Weinmann, 1994, pp. 129-130.

62 Tato, 2017, pp. 120-121; Fuentes Codera, 2014, pp. 155-170.

63 Tato, 2010, pp. 37-48.
} 
rica Latina - como en España. Como afirmaba el historiador francés Paul-Henri Michel, frente a esta aparente antítesis, «hispanismo»y «neutralismo» parecían confundirse en su lucha contra los Aliados y el panamericanismo ${ }^{64}$.

Desde los primeros meses de la guerra, los proyectos latinistas, hispanistas e hispanoamericanistas habían estado en el eje de las discusiones. En Argentina, intelectuales como Alberto Tena habían escrito en mayo de 1915 que las supuestas tensiones entre América Latina y Estados Unidos no eran más argumentos inventados por la propaganda alemana. Desde su punto de vista, los planteamientos sobre la política internacional pacífica y mesurada del país del norte eran «suficientes para destruir la leyenda» de la «rapacidad» de Estados Unidos sobre América ${ }^{65}$. En este contexto, la apelación a la latinidad - un concepto, como es conocido, que estaba anclado en la propaganda francesa hacia América Latina desde mediados del siglo XIX - estuvo estrechamente relacionada con la aliadofilia. Así lo expresó Leopoldo Lugones, quien, en mayo de 1916, en un texto escrito en homenaje a la memoria de Rubén Darío, le calificó como un «un hijo espiritual de Francia», que había sabido posicionarse junto a ella con el objetivo de salvar la «propia» civilización ${ }^{66}$. Sus argumentos no eran demasiado diferentes de los de Ramón Melgar, quien afirmó que la «raza latina» defendía la causa de «la democracia, el derecho y la civilización». En este contexto, sostenía que solamente España se mantenía apartada de «los pueblos de su misma sangre» ${ }^{67}$. Exactamente la misma idea se había planteado unos meses antes en un libro que recogía textos publicados previamente en Mercure de France por autores latinoamericanos como José Enrique Rodó, Santiago Pérez Triana - director en Londres de la revista mensual Hispania -, el chileno Alberto Mackenna Subercaseaux, y los argentinos «Almafuerte», Francisco Barroetaveña y Alejandro Sux: «Si l'Amérique espagnole est, par le sang, la fille de l'Espagne, par la pensé elle est celle de la France» ${ }^{68}$.

Para los partidarios de los Aliados, quienes en Argentina y España reclamaban una tradición «francesa» secular, la neutralidad se construyó como un símbolo de la decadencia nacional en ambos países. La denuncia

\footnotetext{
${ }^{64}$ Michel, 1931,pp. 81 y 87-88.

65 Tena, 1915, pp. 45-46.

66 Lugones, 1917, pp. 143-145.

67 Melgar, 1918, pp. 46-48.

68 Contreras, 1917, p. 21.
} 
de la política gubernamental se combinó con un reclamo de revitalización nacional. Ambos sectores aliadófilos, el argentino y el español, reivindicaron una perspectiva nacional «más europea». Nacionalismo e internacionalismo parecían compatibles en nombre del liberalismo y la democracia. Así, se apeló en este sentido a la unidad espiritual y cultural entre Francia y Latinoamérica anclada en la pertenencia común a la latinidad, una raza cultural definida por su raíz lingüística y opuesta a las razas germánica y sajona. Esto se expresó en diversas manifestaciones que tuvieron lugar en Buenos Aires con motivo de la celebración del 14 de julio en 1917. Allí, junto a las representaciones oficiales de los Aliados, se observó la presencia de las comunidades catalana y española, que exhibían una pancarta con la leyenda «Liga Antigermanófila» y en sus discursos resaltaban una supuesta continuidad entre la resistencia contra Napoleón, la España liberal y la Bélgica mártir ${ }^{69}$.

En este marco, la defensa de los Aliados daba forma a un «genio latino»-que por supuesto incluía a España y sus antiguas colonias- que se conformaba como horizonte nacionalizador y antítesis de lo que representaba Alemania. Se trataba de un horizonte que pretendía incluir al hispanoamericanismo y que, en cierta manera, reproducía también, al menos parcialmente, los debates que tenían lugar en España. Así lo mostraba el comandante Haldane MacFall en un texto publicado en una de las revistas porteñas de mayor circulación: «El alemán odia al inglés y al americano con el más profundo de los odios; pero desprecia al español y a los descendientes de los españoles. (...) El verdadero hispanoamericano se escapa completamente a su mentalidad brutal». La conclusión era clara: frente al alemán, «el hispanoamericano ama la libertad». A pocos meses de finalizar la guerra aún se intentaba acabar con una Alemania a la que se presentaba como enemiga de la democracia y representante de la máxima violencia. Frente a ella, las imágenes conocidas de Francia y la latinidad como garantes de la paz y la civilización continuaban totalmente vigentes $^{70}$.

La disputa por España, su reivindicada latinidad y su posición frente a la guerra se construía transnacionalmente. Así lo mostró la revista Fray Mocho afirmando que, «a pesar de la neutralidad oficial», «el corazón de

69 «La gran manifestación por Francia. El día de ayer. Discursos y desfiles», El Diario, 16 de julio de 1917.

${ }^{70}$ Comandante Haldane MacFall, «La paz alemana y las repúblicas hispanoamericanas», Fray Mocho, 22 de octubre de 1918. 
España» estaba con Francia. Su número del 13 de agosto de 1918 estuvo dedicado a España y contó con artículos del líder reformista Melquíades Álvarez, Emilio Carrere, Jacinto Octavio Picón, Ramón Pérez de Ayala y Ángel Guerra. Como Argentina, España formaba parte de la «raza latina» y estaba con Francia, «nuestra hermana en la preclara trinidad latina», «el genio de la Libertad» ${ }^{71}$. Sus argumentos no estaban lejos de los de Nosotros, la revista cultural más relevante en Argentina, que en un artículo del uruguayo Wilfredo Pi mostró hacia finales de 1917 que las voces de algunos intelectuales españoles aliadófilos, como la de Álvaro Alcalá Galiano, eran fundamentales para mostrar que se trataba de una lucha defensiva de Francia e Inglaterra contra una Alemania avasallante que fundamentaba su espíritu expansivo y de dominación en las obras de filósofos como Hegel y Fichte ${ }^{72}$. En este marco, no era extraño que la madrileña España sostuviera ideas cercanas a un nuevo hispanismo espiritual y cultural ${ }^{73}$.

La entrada de los Estados Unidos en la guerra en 1917 y el nuevo impulso dado a la campaña panamericanista reactivó la hispanofilia. En Argentina, la exaltación de España, que tuvo en el gobierno de Yrigoyen un protagonista fundamental, pretendía neutralizar simbólicamente la influencia de los Estados Unidos y defender la neutralidad adoptada desde el comienzo de la guerra por el gobierno argentino. La propaganda alemana y los círculos germanófilos (también los que aparecieron en la comunidad española) dieron impulso al panhispanismo potenciando la denuncia de los efectos del imperialismo británico y francés sobre los intereses latinoamericanos que se había formulado en los años anteriores desde revistas como Germania. El escritor español residente en Buenos Aires Pedro de Córdoba lo ejemplificó en un pequeño libro. Con una cubierta verdaderamente explícita en la que se veía un águila norteamericana que tenía entre sus garras una bandera brasileña y estaba a punto de abalanzarse sobre otra argentina, ponía de relieve el rechazo radical al panamericanismo y la necesidad de una política de unidad hispanoamericana que hasta ahora, sin embargo, no había sido más que un mero producto literario $^{74}$. Estos argumentos no estaban lejos de los que planteaba el principal periódico germanófilo argentino, La Unión:

71 «Francia juzgada por los españoles», Fray Mocho, 13 de agosto de 1918.

72 «Wilfredo Pi, «El concepto nietzschiano y la Alemania actual», Nosotros, octubre de 1917, pp. 187-192.

73 Albert Ghiraldo, «La ruta de América», España, 10 de mayo de 1917.

74 Córdoba, 1917. 
«El porvenir y la soberanía de las naciones latinoamericanas responden hoy esencialmente de la resistencia alemana; si esta desapareciera, estamos convencidos de que el acuerdo entre los dos grandes países anglosajones no tardaría en llegar, y todas las declaraciones de Wilson sobre la libertad, la democracia y el derecho quedarían reducidas, en el terreno de los hechos, a que se reconociera a su nación la libertad de explotar económicamente todo el continente» ${ }^{75}$.

Para los germanófilos de ambos países ser nacionalista equivalía a defender la neutralidad. Por ello, en la mayoría de manifestaciones no se permitían más que banderas nacionales - argentinas o españolas - y blancas. El contraste entre las imágenes plagadas de banderas aliadas que publicaban los principales periódicos que cubrían las manifestaciones callejeras en Buenos Aires, Córdoba, Madrid o Barcelona era evidente ${ }^{76}$.

En este marco, y parcialmente como expresión de la defensa de su política neutralista frente a la creciente presión de los «rupturistas», el presidente Hipólito Yrigoyen instituyó en 1917 el 12 de octubre como fiesta nacional, el «Día de la Raza», en Argentina. Se trató de un proceso que tuvo como precedente una activa campaña de la Unión Ibero-Americana durante toda la guerra, que buscó conferir a esta fecha un valor simbólico de paz y solidaridad y que tuvo en intelectuales germanófilos españoles como José María Salaverría voces destacadas ${ }^{77}$. En el contexto del recrudecimiento de la lucha política interna en ambos países, como sostuvo Lucio Moreno, las ideas sobre el papel de España en la Historia de América que había presentado la revista Germania editada en Buenos Aires meses atrás fueron utilizadas por el presidente argentino para justificar la instauración de esta nueva celebración nacional ${ }^{78}$. Mientras que La Unión afirmó que el 12 de octubre era «un día tan profundamente americano» como «una fecha española», los sectores favorables a los aliados denunciaron que «los españoles se entusiasman con el señor Yrigoyen. No es extraño: ya se sabe que casi todos los españoles son germanófilos» ${ }^{79}$.

El 12 de octubre de 1917, el día en que se instauraba dicha celebración, el gobierno había aprobado la realización de un mitin neutralista 2018

75 «Teoría y práctica», La Unión, 6 de noviembre de 1918. Sobre La Unión: Tato,

76 Tato, 2017, p. 127; Fuentes Codera, 2014, pp. 160-164.

77 Marcilhacy, 2010, pp. 516-517.

78 Moreno Quintana, 1928, pp. 400-402. La referencia, en Sánchez, 2014, p. 227.

79 La Época, 4 de octubre de 1917. 
multitudinario en Buenos Aires. Todos los sectores proaliados argentinos criticaron duramente al presidente mientras que los sectores germanófilos lo defendieron ${ }^{80}$. Alfredo Colmo, jurista y uno de los principales intelectuales neutralistas argentinos, había preparado un discurso para la gran manifestación prevista para el 12 de octubre de 1917. A pesar de que la lluvia acabó obligando a suspender el acto, éste acabo apareciendo en su libro Mi neutralismo meses más tarde. El texto muestra los vínculos entre el hispanismo y el neutralismo y cómo estos configuraban una dura crítica de otros proyectos latinistas y panamericanistas. La influencia de la neutralidad española ocupaba un espacio destacado y la fecha era perfecta para ponerla de relieve: «Recordemos a la madre patria, que con toda altivez resiste, en medio de necesidades más intensas que las nuestras, influencias aún más directas que las que obran contra nosotros». España, como Holanda, Suecia y Noruega, eran ejemplos de «valentía» y «decencia». En este marco, el panamericanismo no era más que la expresión de la voluntad imperialista de Estados Unidos que se imponía a otros países «que son como sucursales de aquel». La única solución, frente a este panamericanismo «deformado» era que Argentina se mantuviera neutral ${ }^{81}$.

Al amparo de la actividad de la Unión Ibero-Americana, los germanófilos reivindicaron un acercamiento a España. La perspectiva que asumieron se asentaba en los planteamientos previos de Manuel Ugarte. A pesar de que no había sido un defensor de Alemania, había sido un duro crítico del panamericanismo y había reivindicado en los años anteriores a la guerra una revalorización de las raíces hispánicas interpretadas en clave americanista. Por supuesto, los germanófilos podían «manipular» estos elementos para situarlo junto a ellos. Así lo mostraba La Unión al comentar la invitación del Centro Cultural Hispanoamericano de Madrid a Ugarte para pronunciar unas conferencias en octubre de $1918^{82}$.

En una acción de política exterior, un año más tarde el 12 de octubre de 1918 quedaba instaurado como fiesta nacional en España. En Argentina, diarios de todo el país saludaron esta noticia y la enmarcaron en un «movimiento confraternizador» iniciado años atrás y que había tenido el año anterior un punto de inflexión con la instauración del Día de la Raza

80 Tato, 2010, pp. 46-47.

81 Colmo, 1918, pp. 66, 74, 88 y 91.

82 «Relaciones intelectuales con España. Invitación a Don Manuel Ugarte», La Unión, 4 de octubre de 1918. 
en Argentina ${ }^{83}$. La Unión celebró esta fecha con especial énfasis y anunció que «un feliz renacimiento» parecía anunciarse entre los países americanos y la «vieja España» ${ }^{84}$. Justamente el 12 de octubre aparecía en este periódico un largo artículo sobre «la epopeya de la raza» acompañado de otro mucho más breve titulado «iLa paz!» en el que se anunciaba que Alemania había aceptado «las catorce condiciones propuestas por el presidente norteamericano». Con ello demostraba que siempre había deseado la paz y que no aspiraba a «dominar» el mundo ${ }^{85}$. Neutralidad, pacifismo y las políticas de los gobiernos argentino y español formaba un conjunto cerrado, que se había expresado durante toda la guerra y que había tenido, hacia el final del conflicto, un intento de proyección internacional por parte de Yrigoyen en la fallida celebración de un «Congreso de Neutrales» en Buenos Aires en marzo de $1918^{86}$.

La polémica argentina apareció también con claridad en España, ya que mientras que voces favorables a Alemania volvieron a destacar los vínculos entre neutralidad e hispanismo, intelectuales pro aliados, como Eduardo Gómez de Baquero, escribieron que «una parte de España ha dado a la América hispana el espectáculo de una germanofilia pareja con la de Turquía, ¡a esa América, vibrante de entusiasmo por Francia, llena de admiración hacia el gran ejemplo moral de los Estados Unidos! ${ }^{87}$. Miguel de Unamuno, por su parte, manifestó su negativa a celebrar una fiesta «de la Raza» en un momento en que lo que debía hacerse era intervenir en la guerra para celebrar la fiesta «de la Humanidad» ${ }^{88}$.

Las celebraciones de este año hicieron emerger una cierta tensión alrededor del concepto que se expresó más allá de Buenos Aires. Así se observó en un periódico del Chaco argentino en el que, desde la defensa del Día de la Raza, se apuntaba que no podía dejarse de lado el contexto de la guerra: «En los momentos actuales no se concibe que se realicen fiestas de esa índole patriótica sin que se les dé una finalidad doblemente noble; la primera como afirmación de nacionalismo y como exaltación de la pro-

\footnotetext{
${ }^{83}$ «La Fiesta de la Raza. España la hace ley», La Voz del Chaco, 5 de septiembre de 1918.

84 «12 de octubre. La Fiesta de la Raza», La Unión, 11 de octubre de 1918.

85 «La epopeya de la raza» y « ¿La Paz!», La Unión, 12 de octubre de 1918. Véase también «La verdad sobre la guerra», La Unión, 14 de octubre de 1918.

86 Weinmann, 1994, p. 117.

87 Andrenio, «Crónica de la semana. La gran fecha», Nuevo Mundo, 18 de octubre de 1918.

${ }^{88}$ La referencia, en Rachum, 2004, p. 71.
} 
pia estirpe; la segunda como afirmación de los nobles sentimientos humanos y por ende de solidaridad fraternal». Efectivamente, la fiesta en cuestión no podía dejar fuera a «todos los pueblos de la misma raza del pueblo español: de la raza latina». Por tanto, el Día de la Raza no podía convertirse en una defensa de la neutralidad, sino en una afirmación de los valores representados por Francia e Italia en la guerra ${ }^{89}$.

Como resultado de la derrota alemana, las celebraciones a favor de los Aliados ocuparon las principales calles argentinas. En este marco, el gobierno argentino decretó el 4 y el 14 de julio días festivos nacionales en 1919. El 14 de julio fue incorporado de manera permanente en varios países latinoamericanos. Sin embargo, esta fecha, a diferencia del 12 de octubre, acabaría desapareciendo del calendario festivo. Algo parecido sucedió en las calles de las principales ciudades españolas. También muchos ayuntamientos organizaron numerosos actos y reivindicaron la tradición latina ${ }^{90}$. Entre los intelectuales germanófilos, las percepciones sobre la posición argentina al final de la guerra no fueron las mismas que entre los partidarios de la ruptura de relaciones con Alemania. «Argentina se ha engrandecido (...) con relación a su dignificación y exaltación internacionales. Nadie podrá reprocharle su entereza para resistir tantas sugestiones y amenazas como las que ha sufrido de parte de los aliados», escribió Alfredo Colmo hacia el final del conflicto. La responsabilidad de la «posición envidiable» de Argentina se debía en primer lugar a su presidente, que había sabido mantenerse firme frente a las presiones. Argentina se situaba así, junto a otras naciones que también habían «impuesto el dogma de su propia neutralidad y del respeto de sus derechos soberanos», como los países escandinavos, Suiza, Holanda, Chile, México y España. Las tres últimas eran especialmente relevantes porque eran «la más alta representación del espíritu castellano». Los países «más independientes del mundo» se habían mantenido neutrales, mientras que los más dependientes habían abrazado la causa aliada. Los que habían resistido, los que se habían horrorizado frente «a la carnicería humana de la guerra» y los que habían velado «por los derechos escarnecidos de una humanidad en trance epiléptico de demencia y autodestrucción» habían sido los países que se habían mantenido neutrales. La paz y la neutralidad, como al principio de la guerra, continuaban siendo argumentos fundamentales ${ }^{91}$.

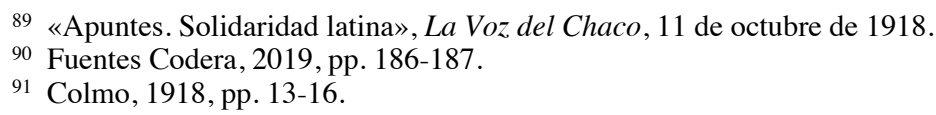


En este contexto, diversas iniciativas editoriales pretendieron impulsar un proyecto hispanista renovado a ambos lados del Atlántico para hacer frente a las derivaciones latinistas y panamericanistas de la guerra. Una de ellas fue Raza Española, dirigida desde Madrid por Blanca de los Ríos. Otra expresión de este mismo propósito fue el semanario América Hispana, dirigido desde Buenos Aires por Julián de Charras. Su primer número se publicó en julio de 1920 y mostró una amplia nómina de colaboradores de diversos países americanos, además de España y Portugal. El primer punto de sus «Propósitos» tenía una cierta reminiscencia a los debates que se habían desplegado durante la guerra: «Velar por el respeto a la verdad histórica y la Justicia, en lo que se refiere a la grandiosa obra de España en los orígenes y desenvolvimiento de la civilización y progreso de América». Entre sus impulsores destacaba Pablo Soler y Guardiola, entonces embajador de España en Argentina, y Marco Avellaneda, ex embajador de Argentina en España. Tenía, por tanto, el apoyo de las más altas esferas políticas. Nacía con el objetivo de desplegar el proyecto de una «América hispana» contra los diversos intentos de construir una «América Latina»o «Latinoamérica» nacidos al calor del «desconcierto universal» que había originado la guerra ${ }^{92}$. Por ello, no era extraño que el primer artículo de la revista, firmado por el escritor español Miguel de Zárraga, estuviera dedicado a esta cuestión. La referencia a José Enrique Rodó y su Ariel era utilizada aquí para fundamentar la necesidad de recuperar la centralidad de España y Portugal en América: «debemos llamarnos "hispanoamericanos", nietos de la heroica y civilizadora raza que sólo políticamente se ha fragmentado en dos naciones europeas ${ }^{93}$. Se trataba de una intensa disputa que continuaría con fuerza en las décadas posteriores ${ }^{94}$.

La visión hispanista se cruzaba con la herencia de la guerra. En un largo artículo con reminiscencias cercanas a los planteamientos germanófilos transatlánticos se destacaba la figura de Alfonso XIII y «su grandeza moral durante la guerra europea». El texto, encabezado por la leyenda «¡Por la verdad y la justicia!», realzaba su obra humanitaria, que le había valido los homenajes desde Francia y Bélgica. El monarca español había sabido «conservar durante toda la guerra una neutralidad noble, hidalga, en la que vibraba toda la generosidad de la raza y en la que se podían basar todas las garantías futuras». Alfonso XIII había conducido a España a

\footnotetext{
92 «En voz alta», América Hispana, julio de 1920.

93 Miguel de Zárraga, «iHispanos, no latinos!», América Hispana, julio de 1920.

94 Marcilhacy, 2015.
} 
«definir libre y claramente su posición». Había defendido su independencia frente a una Europa en decadencia que pretendía avasallarla ${ }^{95}$. El tercer número de la revista estuvo dedicado a la festividad del 12 de octubre, el Día de la Raza. Su editorial estaba firmado por Marco Avellaneda y uno de sus textos más relevantes, obra de José María Salaverría, uno de los intelectuales más importantes del pequeño arco germanófilo español, estaba dedicado a la figura de Francisco Pizarro ${ }^{96}$.

En un libro publicado en 1931, Paul-Henri Michel sostuvo que desde el inicio de la guerra América Latina había estado dividida en dos sectores, el aliadófilo y el germanófilo. En una especie de balance del papel jugado por los intelectuales latinoamericanos durante el conflicto, sostenía que entre 1914 y 1917 la mayoría favorable a los Aliados había ido equilibrándose hasta que, con la entrada de Estados Unidos en la guerra, el debate sobre la intervención se había convertido en un fenómeno «americano». En este marco, los proyectos panamericanistas se habían convertido en mayoritarios y habían dificultado la proyección de una visión «hispánica». Con el conflicto europeo, dicho panamericanismo se había desplegado en estrecha relación y sin aparentes contradicciones con la idea de una «raza latina» compartida con Francia. Así, la oposición entre panamericanismo e hispanismo era «sans doute le plus grand problème politique de l'Amérique latine»: «En face des problèmes également vitaux pour elle, quoique pour des raisons diverses, de ses relations avec les États-Unis, avec le monde latin, avec l'Espagne», América Latina estaba profundamente dividida ${ }^{97}$. La disputa por la denominación continental - «América Latina» o «América Hispana» - se había convertido en un debate central.

A pesar de situarse en el campo opuesto, estas ideas no estaban lejos de las que se habían motivado la aparición de un libro que, editado en Madrid, expresaba el carácter transnacional del hispanismo en los últimos meses de la guerra. Allí, el argentino y miembro de la Real Academia de la Historia J. Francisco V. Silva analizaba el desarrollo de los vínculos entre España y América desde el siglo XV. En su prólogo, firmado en julio de 1918 por el académico español Adolfo Bonilla y San Martín, se

95 «El Rey de España y su grandeza moral durante la guerra Europea», América Hispana, julio de 1920 .

96 José María Salaverría, «La espada de Pizarro», América Hispana, setiembre-octubre de 1920 .

97 Michel, 1931, pp. 55-56, 31 y 41. 
afirmaba que Silva era «netamente nacional (hispánico-argentino) por su nombre y su estirpe (...) por la nobleza de sus ideas». El conflicto estaba próximo a su fin y Bonilla pensaba que no era momento de «dilatar los trabajos de aproximación política entre pueblos tan estrechamente emparentados como España y la América española». La reciente publicación de dos libros, Los exploradores españoles, de Charles Lummis, y La leyenda negra, de Julián Juderías, le llevaban a pensar que se había iniciado «la obra de rehabilitación del pasado hispánico» iniciado por Marcelino Menéndez y Pelayo ${ }^{98}$.

El libro se situaba en el espacio transnacional de las derechas conservadoras transatlánticas que comenzaba a articularse con el fin de la gue$\mathrm{rra}^{99}$. Silva afirmaba que era una «desviación» - directamente relacionada con el uso del concepto francés de «república»- hablar de «América Latina» 0 «Sud-América». Se trataba de un error histórico relacionado con la falta de interés y de políticas claras para atraer hacia España a sus antiguas colonias. Por ello, poniendo fin al «ensayo» del siglo XIX, era necesario trabajar hacia una «re-formación» del Imperio Hispánico, una «unión federal entre España y los países de la América española». Este era un planteamiento que recogía las visiones del mexicano Carlos Pereyra, el venezolano Rufino Blanco-Fombona y el argentino Manuel Ugarte, todos ellos duramente críticos con el panamericanismo impulsado desde los Estados Unidos, y que bebía de fuentes transnacionales que habían afirmado en las décadas previas la necesidad de una revalorización de la herencia hispánica en América. Por ello se citaban también autores como Ricardo Rojas, Manuel Gálvez y José Enrique Rodó, entre otros ${ }^{100}$.

Este planteamiento nacía de lo que había dejado al descubierto la guerra. Al formar el Imperio, España y la América española, y por «lógica histórica», Brasil y Portugal, se había de buscar en esta unión la fuerza, la cohesión necesaria para combatir la «mediatización absorbente» de los Estados Unidos: «España y los países de América española se unen políticamente para vivir libres $s u$ Estado, defendiendo su civilización; si no, Inglaterra, Alemania y Estados Unidos los someterán a un régimen de mediatización más activo, que el vigente desde 1810». Se trataba de impulsar el «pan-hispanismo» como una respuesta a otros imperialismos: el pangermanismo, el panamericanismo, el paneslavismo y los proyectos li-

\footnotetext{
98 Silva, 1918, pp. VI, XII y XIV.

99 González Calleja, 2007.

100 Silva, 1918, pp. VI, XII, XIV y 407-431.
} 
derados por Inglaterra y Japón. El panhispanismo desplazaba al «pan-iberismo» por ser, también, artificial. Sin embargo, alertaba Silva, el desarrollo de este proyecto no era fácil en absoluto, ya que existía una notable hispanofobia en América y en España reinaba la indiferencia hacia una política expansionista. Ambas fuerzas habían creado la «cristalización» de la independencia de $1810^{101}$. El conflicto, insistía, había puesto las bases para la proyección de este ideal panhispanista. Citando a Treistschke, afirmaba que «por encima de los derechos de los individuos» estaban «las prestaciones colectivas, las cuales dan un contenido a la sociedad». La guerra había mostrado que la importancia de «la acción individual bajo una dirección inspirada en el ideal nacional», y el panhispanismo era una expresión de ello, había renovado la «jerarquía de Estados» - la presión de Inglaterra y Estados Unidos era el peligro evidente - y había puesto de relieve la necesidad de «vigorizar» el ser de la «América española». La Gran Guerra había dado una lección a la «América española», con ella había terminado «el siglo de su política romántica hispanófoba con su patriotismo de vicios crónicos» heredado de 1810. El renovado panhispanismo, surgido de «los valerosos sacrificios rendidos por los extranjeros en sus europeos campos de batalla», rechazaba las estrechas visiones nacionalistas, localistas. En esta argumentación, Silva citaba a Antonio Goicoechea, quien había escrito sobre las virtudes de la guerra, su «eficacia pedagógica», su capacidad para, frente a la crisis, «iluminar el alma nacional», y a Vicente Gay, quien había apuntado la necesidad de desarrollar una concepción «internacional»o «mundial» hispánica. Vázquez de Mella también formaba parte de las bases ideológicas sobre las cuales se asentaban estos planteamientos. Esta propuesta panhispanista era simultáneamente una reacción contra los partidarios de la intervención en la guerra, «afrancesados, yankenizados, hispanófobos, hijos de extranjeros, los despreciadores de criollos e indios, los leguleyos ideólogos, pedagogos ridículos» que habían auspiciado una política «anti-hispánica» de «solidaridad intervencionista con Estados Unidos». El nuevo imperio debería enfrentarse a su «reconstitución» política interior y exterior y, en este proceso, el «irredentismo» ocuparía un lugar central. Se trababa de un irredentismo transnacional que habría de centrarse tanto en Europa - el estrecho de Gibraltar-, como en el norte de África - Marruecosy América, donde buscaría la «liberación» de Puerto Rico y las islas Mal-

101 Ibídem, pp. 1-33. 
vinas y alejar la influencia de Estados Unidos de toda América Central y México. Eso permitía concluir a Silva lo siguiente: «Hoy el pan-hispanismo, planteado como programa de alta política, es una creación argentina libre, reversión de toda América española hacia Castilla» ${ }^{102}$. Muchas de las ideas de este intelectual argentino serían fundamentales para configurar los discursos hispanistas asumidos por las derechas reaccionarias durante las décadas posteriores en España y Argentina.

\section{Conclusiones}

En contraste con el desastre europeo, Latinoamérica emergió como una tierra prometida, un mundo pacífico que permanecía formalmente neutral frente a la catástrofe y que condenaba la violencia de su secular faro cultural. Como se observó tanto en Argentina como en España, diversos intelectuales pensaron que el agotamiento de la civilización europea podía conducir al liderazgo de Latinoamérica ${ }^{103}$. Se trató de un latinoamericanismo que se relacionó con la defensa del legado español en América: «La América española puede vivir y viviría mejor sin relaciones con Estados Unidos», había afirmado en julio de 1916 la revista Unión Iberoamericana de Madrid. Era una visión compartida por la revista barcelonesa Mercurio, que en marzo de 1917 y a través de Federico Rahola, había advertido sobre el peligro de la intervención de Estados Unidos en la guerra en relación con los países latinoamericanos ${ }^{104}$.

Este latinoamericanismo convivió con planteamientos hispanistas que pretendieron combatir las influencias latinistas francesas y el panamericanismo impulsado desde Estados Unidos. Se trataba de un largo proceso que tenía raíces interseculares y que durante la celebración del centenario de la Revolución de Mayo se había expresado - no sin controversias intensas - a través de intelectuales como Manuel Gálvez, que habían defendido el panhispanismo como la quintaesencia de la argentinidad. Con la guerra, los sectores más militantemente favorables al hispanismo pretendieron trazar una separación radical entre los conceptos «América Hispana» y «América Latina». En este propósito, la neutrali-

102 Ibídem, p. 464-471 y 504.

103 Compagnon, 2014, pp. 205-245.

104 Federico Rahola, «Un retoño de la doctrina de Monroe», Mercurio, 29 de marzo de 1917. 
dad y el pacifismo se construyeron como elementos fundamentales para articular un espacio transnacional que se expresó con claridad en Argentina y España en los sectores partidarios de las Potencias Centrales, que pretendieron simultáneamente fortalecer las posiciones de los respectivos gobiernos.

Al final del conflicto, las declaraciones universalistas de Woodrow Wilson perdieron toda la potencia que habían proyectado en el mundo ${ }^{105}$. La no ratificación por parte de los Estados Unidos de la adhesión a la Sociedad de Naciones y la llegada del republicano Harding fueron dos elementos centrales para que tanto en España como en Argentina numerosos intelectuales denunciaran la traición que había tenido lugar. Para muchos de ellos, algunos de los cuales habían sido militantemente aliadófilos, Estados Unidos se había convertido en un «peligro» para el mundo ${ }^{106}$. En este marco, el rechazo a la política intervencionista sobre América Latina dio lugar a una notable resistencia a los planteamientos de los Estados Unidos, percibidos como unilaterales. En paralelo, dio fuerza el desarrollo de un renovado hispanoamericanismo que, en disputa con las herencias ibéricas y latinas, se proyectó con éxito durante los años veinte y treinta ${ }^{107}$. En este proceso, los vínculos establecidos durante la guerra entre neutralismo e hispanismo fueron fundamentales.

\section{Fuentes}

Alemania por encima de todo: la mentalidad alemana y la guerra, París, Armand Colin, 1915.

¿Cómo puede ser justa la guerra alguna vez?, Thomas \& Lilly, Londres, 1915.

La verdad de la guerra, Barcelona, Germania, 1916.

Inglaterra ante el espejo de la verdad: juicios de intelectuales de diversas naciones, incluso la británica, sobre el verdadero carácter inglés, Buenos Aires, 1918.

Tercer Censo levantado el 1. ${ }^{\circ}$ de junio de 1914, Talleres Gráficos L. J. Rosso \& Cía., Buenos Aires, 1916.

ANDRÉ, Eloy Luis, La mentalidad alemana, Daniel Jorro, Madrid, 1916.

ARAQUISTÁIN, Luis, El peligro yanqui, Editorial Sempere, Valencia, 1919.

105 Manela, 2007.

106 Araquistáin, 1919.

107 Marcilhacy, 2010, pp. 132-168; Núñez Seixas, 2017. 
BARROETAVEÑA, Francisco, Alemania contra el mundo, Otero \& Co., Buenos Aires, 1916.

COLMO, Alfredo, Mi neutralismo, Biblioteca Renovación, Buenos Aires, 1918.

CONTRERAS, Francisco, Les écrivains hispano-américains et la guerre européenne, Éditions Bossard, París, 1917.

CÓRDOBA, Pedro de, Nuestra guerra. La coalición contra la Argentina, La Gaceta de España, Buenos Aires, 1917.

LUGONES, Leopoldo, Mi beligerancia, Otero y García editores, Buenos Aires, 1917.

MELGAR, Ramón, La democracia y la guerra, Librería de A. García Santos, Buenos Aires, 1918.

MELGAR, Ramón, Germany and Spain. The views of a Spanish Catholic, T. Fisher Unwin, Londres, 1916.

MICHEL, Paul-Henri, L'Hispanisme dans les Républiques Espagnoles d'Amérique pendant la guerre de 1914-1918, Alfred Costes Éditeur, París, 1931.

MORENO QUINTANA, Lucio, La diplomacia de Irigoyen, Inca, La Plata, 1928.

QUESADA, Ernesto, La actual civilización germánica y la presente guerra, Buenos Aires, 1914.

RAMOS, Juan P., La significación de Alemania en la guerra europea, Buenos Aires, 1915.

SILVA, J. Francisco V, Reparto de América Española y Pan-Hispanismo, Francisco Beltrán, Madrid, 1918.

TENA, Alberto, La otra Alemania, A. Moen y Hermano, Buenos Aires, 1915.

\section{Bibliografía}

ABBENHUIS, Maartje, «Not silent nor silenced: Neutrality and the First World War», en José Luis Ruiz Sánchez, Inmaculada Cordero Oliverio y Carolina García Sanz (eds.), Shaping Neutrality throughout the First World War, Universidad de Sevilla, Sevilla, 2016, pp. 17-36.

ALBES, Jens, «La propaganda cinematográfica de los alemanes en España durante la Primera Guerra Mundial», Mélanges de la Casa de Velázquez, 31/3, 1995, pp. 77-101.

ALCALDE, Ángel, «Spatializing Transnational History: European Spaces and Territories», European Review of History: Revue européenne d'histoire, 25/3-4, 2018, pp. 553-567.

ALONSO, Gregorio, «"Afectos caprichosos": tradicionalismo y germanofilia en España durante la Gran Guerra», Hispania Nova, 15, 2017, pp. 394-415.

AUBERT, Paul, «La propagande étrangère en Espagne dans le premier tiers du xxe siècle», Mélanges de la Casa de Velázquez, 31/3, 1995, pp. 103-176. 
Hispanismo y neutralismo: articulaciones transnacionales en España y Argentina...

BARRAL MARTÍNEZ, Margarita, «De neutralidad obligada a neutralidad activa a través de la acción humanitaria: Alfonso XIII y la Oficina Pro-Cautivos durante la Gran Guerra», en Carlos Sanz Díaz y Zorann Petrovici, La Gran Guerra en la España de Alfonso XIII, Sílex, Madrid, 2019, pp. 117-138.

COMPAGNON, Antoine, América Latina y la Gran Guerra. El adiós a Europa (Argentina y Brasil, 1914-1939), Crítica, Buenos Aires, 2014.

COMPAGNON, Antoine y PURSEIGLE, Pierre, «Géographies de la mobilisation et territoires de la belligérance durant la Première Guerre Mondiale», Annales. Histoire, Sciences Sociales, 71/1, 2016, pp. 37-64.

FIGALLO, Beatriz, Argentina y España: entre la pasión y el escepticismo, CONICET-Teseo, Buenos Aires, 2014.

FRANK, Robert, «1914-1918: une guerre mondiale ou une guerre-monde?» Histoire, Espaces, Relations, 9, 2016, pp. 9-21.

FUENTES CODERA, Maximiliano, «1917, a Turning Point in neutral countries. Great War and Russian Revolution in Spain (and Argentina)», en Gerhard Besier y Katarzyna Stoklosa (eds), 1917 and the Consequences, Routledge, Londres, 2020, pp. 131-146.

FUENTES CODERA, Maximiliano, «Volver a la Gran Guerra: sobre la relación entre los debates políticos e intelectuales y su impacto en la sociedad española», en Carlos Sanz Díaz y Zorann Petrovici, La Gran Guerra en la España de Alfonso XIII, Sílex, Madrid, 2019, pp. 169-188.

FUENTES CODERA, Maximiliano, España en la Primera Guerra Mundial. Una movilización cultural, Akal, Madrid, 2014.

GARCÍA SANZ, Carolina, «Repensar la neutralidad en la Gran Guerra. Una lectura en clave europea», en Pedro Ruiz (ed.), Volver a pensar el mundo de la Gran Guerra, Institución Fernando El Católico, Zaragoza, 2016, pp. 183202.

GARCÍA SANZ, Carolina y Tato, María Inés, «Neutralist crossroads: Spain and Argentina facing the Great War», First World War Studies, 8, 2017, pp. 115132.

GERWARTH, Robert y MANELA, Erez (eds.), Imperios en guerra, 1911-1923, Biblioteca Nueva, Madrid, 2015.

GONZÁLEZ CALLEJA, Eduardo (coord.), Anatomía de una crisis. 1917 y los españoles, Alianza, Madrid, 2017.

GONZÁLEZ CALLEJA, Eduardo, «El hispanismo autoritario español y el movimiento nacionalista argentino: balance de medio siglo de relaciones políticas e intelectuales (1898-1946)», Hispania, 226, 2007, pp. 599-642.

GONZÁLEZ CALLEJA, Eduardo y AUBERT, Paul, Nidos de espías. España, Francia y la Primera Guerra Mundial (1914-1919), Madrid, Alianza, 2014.

GUPTA, Akhil, «The Song of the Nonaligned World: Transnational Identities and the Reinscription of Space in Late Capitalism», Cultural Anthropology, 7/1, 1992, pp. 63-79. 
HORNE, John, «Foreword», en James Kitchen, Alisa Miller y Laura Rowe (eds.), Other Combatants, Other Fronts: Competing Histories of the First World War, Cambridge Scholars Publishing, Newcastle, 2011, pp. xiii-xvi.

HORNE, John y KRAMER, Alan German Atrocities, 1914. A History of Denial, Yale University Press, New Haven y London, 2001.

KRUIZINGA, Samuel, «Neutrality», en Jay Winter (ed.), The Cambridge History of the First World War: Volume II: The State, Cambridge University Press, Cambridge, 2014, pp. 542-675.

LANÚS, Juan Archibaldo, Aquel apogeo. Política internacional argentina, 19101939, Emecé, Buenos Aires, 2001.

MANELA, Erez, The Wilsonian Moment: Self-Determination and the International Origins of Anticolonial Nationalism, Oxford University Press, Oxford, 2007.

MARCILHACY, David, ““Nada de latinismos!”. Amérique "latine” ou Amérique "hispanique"», Cahiers d'études romanes, 30, 2015, pp. 199-222.

MARCILHACY, David, Raza Hispana. Hispanoamericanismo e imaginario nacional en la España de la Restauración, CEPC, Madrid, 2010.

MARTORELL LINARES, Miguel, «No fue aquello solamente una guerra, fue una revolución»: España y la Primera Guerra Mundial, Historia y Política, 26, 2011, pp. 17-45.

MULLIGAN, William, «The First World War in a Global Age», European History Quarterly, 46/2, 2016, pp. 311-326.

MULLIGAN, William, The Great War for Peace, Yale University Press, New Haven, 2014.

NEIBERG, Michael, Fighting the Great War: A global history, Harvard University Press, Cambridge, 2005.

NEIBERG, Michael, Dance of the furies. Europe and the outbreak of World War I, Cambridge University Press, Cambridge, 2011.

NÚÑ̃Z SEIXAS, Xosé Manoel, «¿Negar o reescribir la Hispanidad? Los nacionalismos subestatales ibéricos y América Latina, 1898-1936», Historia Mexicana, 265, 2017, pp. 401-458.

OLSTEIN, David, Thinking History Globally, Palgrave, Basingstoke, 2014.

PONCE, Javier, «Propaganda and Politics: Germany and Spanish Opinion in World War I», en Troy Paddock (ed.), World War I and Propaganda, Brill, Connecticut, 2014, pp. 292-321.

RACHUM, Ilan, «Origins and Historical Significance of Día de la Raza», Revista Europea de Estudios Latinoamericanos y del Caribe, 76, 2004, pp. 61-81.

RINKE, Stefan y WIDT, Michael (eds.), Revolutions and Counter-Revolutions. 1917 and its Aftermath from a Global Perspective, Campus, Frankfurt y Nueva York, 2017.

ROLLAND, Denis, La crise du modèle français. Marianne et l'Amerique latine. Culture, politique et identité, Presses Universitaires de Rennes, Rennes, 2000. 
Hispanismo y neutralismo: articulaciones transnacionales en España y Argentina...

ROMERO SALVADÓ, Francisco, España 1914-1918. Entre la guerra y la revolución, Crítica, Barcelona, 2002.

ROSENBUSCH, Anne, «Guerra total en territorio neutral: actividades alemanas en España durante la Primera Guerra Mundial», Hispania Nova, 15, 2017, pp. 350-372.

SÁNCHEZ, Emiliano, «Pasión de multitudes. La prensa y la opinión pública de Buenos Aires frente al estallido de la Gran Guerra», Anuario IEHS, 33, 2018, pp. 177-204.

SÁNCHEZ, Emiliano, Guerra de palabras. Representaciones, debates y alineamientos de la prensa y la opinión pública de Buenos Aires ante la Gran Guerra (1914-1919), Tesis Doctoral, Universidad de Buenos Aires, Buenos Aires, 2014.

STEVENSON, David, 1917. War, Peace and Revolution, Oxford University Press, Oxford, 2017.

STURFELT, Lina, «The Call of the Blood: Scandinavia and the First World War as a Clash of Races», en Claes Ahlund (ed.). Scandinavia in the First World War: Studies in the War Experience on the Northern Neutrals, Nordic Academic Press, Lund, 2012, pp. 199-224.

TAMES, Ismee, «War on Our Minds: War, neutrality and identity in Dutch public debate during the First World War», First World Studies, 2, 2012, pp. 201-216.

TATO, María Inés, «Fighting for a Lost Cause? The Germanophile Newspaper La Unión in Neutral Argentina, 1914-1918», War in History, 25/4, 2018, pp. 464-484.

TATO, María Inés, La trinchera austral. La sociedad argentina ante la Primera Guerra Mundial, Prohistoria Ediciones, Rosario, 2017.

TATO, María Inés, «Germanófilos versus aliadófilos. La colonia española de Buenos Aires frente a las polarizaciones de la Gran Guerra», en Nadia Andrea de Cristóforis y María Inés Tato (eds.), Las grandes guerras del siglo XX y la comunidad española de Buenos Aires, Editorial Filo Uba, Buenos Aires, 2014, pp. 15-43.

TATO, María Inés, «La contienda europea en las calles porteñas. Manifestaciones cívicas y pasiones nacionales en torno de la Primera Guerra Mundial», en María Inés Tato y Martín O. Castro (comps.), Del Centenario al peronismo. Dimensiones de la vida política argentina, Imago Mundi, Buenos Aires, 2010, pp. 33-63.

WEINMANN, Ricardo, Argentina en la Primera Guerra Mundial: neutralidad, transición política y continuismo económico, Biblos, Buenos Aires, 1994.

WELCH, David, Germany and Propaganda in World War One: Pacifism, Mobilization and Total War, Tauris, Londres, 2014.

WINTER, Jay (ed.), The Cambridge History of the First World War. Volume I, Cambridge University Press, Cambridge, 2014. 


\section{Financiación}

Este artículo forma parte de los resultados del proyecto «La patria hispana, la raza latina. Intelectuales, identidades colectivas y proyectos políticos entre España, Italia y Argentina (1880-1945)» (Programa estatal de fomento de la investigación científica y técnica de excelencia - Subprograma estatal de generación de conocimiento. Ministerio de Industria, Economía y Competitividad, ref. HAR2016-75324-P).

\section{Datos del autor}

Maximiliano Fuentes Codera es profesor en la Universidad de Girona, donde también dirige la cátedra Walter Benjamin, Memoria y Exilio. Ha dedicado una parte relevante de sus publicaciones a la Primera Guerra Mundial. Es investigador principal del proyecto internacional «La patria hispana, la raza latina. Intelectuales, identidades colectivas y proyectos políticos entre España, Italia y Argentina (1880-1945)». Entre sus últimos trabajos destacan los libros Un viaje por los extremos. Eugenio d'Ors en la crisis del liberalismo (2017) y España en la Primera Guerra Mundial. Una Movilización cultural (2014) y, como editor, A Civil War of Words (2016, junto a Xavier Pla y Francesc Montero) e Ideas comprometidas. Los intelectuales y la política (2018, con Ferran Archilés). En la actualidad prepara un libro titulado Spain and Argentina in the First World War. Transnational Neutralities, que aparecerá en 2020 en Routledge y, en su versión en castellano, en Marcial Pons. 